\title{
The fish family Muraenidae: an ideal group for testing at small-scale the coherency of Macaronesia as a biogeographic unit, with the first report on separate fishery statistics
}

\author{
José A. González ${ }^{1}$, Sandra Correia ${ }^{2}$, Sebastián Jiménez ${ }^{3}$, Carlos A. Monteiro ${ }^{2}$, João Delgado ${ }^{4}$, \\ Mário R. Pinho ${ }^{5}$, José M. Lorenzo ${ }^{1}$, Gustavo González-Lorenzo ${ }^{3}$ \\ ${ }^{1}$ Applied Marine Ecology and Fisheries, i-UNAT, University of Las Palmas de Gran Canaria, Campus de Tafira, 35017 \\ Las Palmas de Gran Canaria, Spain. \\ (JAG) (Corresponding author) E-mail: pepe.solea@ulpgc.es. ORCID-iD: http://orcid.org/0000-0001-8584-6731 \\ (JML) E-mail: josemaria.lorenzo@ulpgc.es. ORCID-iD: http://orcid.org/0000-0003-3752-5209 \\ ${ }^{2}$ Instituto do Mar, Cova de Inglesa, CP 132, Mindelo, São Vicente, Cabo Verde. \\ (SC) E-mail: sandra.correia@imar.gov.cv. ORCID-iD: http://orcid.org/0000-0001-7619-2801 \\ (CAM) E-mail: monteiro.carlos@imar.gov.cv. ORCID-iD: http://orcid.org/0000-0002-1348-541X \\ ${ }^{3}$ Spanish Institute of Oceanography (IEO), Centro Oceanográfico de Canarias, Farola del Mar 22, Dársena Pesquera, \\ 38180 Santa Cruz de Tenerife, Spain. \\ (SJ) E-mail: sebastian.jimenez@ieo.es. ORCID-iD: https://orcid.org/0000-0002-6534-4096 \\ (GG-L) E-mail: jgustavo.gonzalez@ieo.es. ORCID-iD: https://orcid.org/0000-0002-9594-7648 \\ ${ }^{4}$ Direção Regional do Mar, Serviço de Monitorização, Estudos e Investigação, Avenida do Mar e Comunidades \\ Madeirenses 23, $1^{\circ} \mathrm{E}, 9000-054$ Funchal, Madeira, Portugal. \\ (JD) E-mail: joao.delgado@ madeira.gov.pt. ORCID-iD: http://orcid.org/0000-0003-4268-7202 \\ ${ }^{5}$ IMAR Institute of Marine Research / Okeanos R\&D Centre / Department of Oceanography and Fisheries - \\ University of the Azores, 9901-862 Horta, Azores, Portugal. \\ (MRP) E-mail: mario.rr.pinho@uac.pt. ORCID-iD: http://orcid.org/0000-0002-8045-2546
}

\begin{abstract}
Summary: The present study was conceptualized to study the muraenid species (moray eels) occurring around the volcanic archipelagos of the Azores, Madeira, Selvagens, Canary and Cabo Verde islands (eastern-central Atlantic). The biogeographic patterns of these species were analysed and compared. We then hypothesized that this fish family is an ideal group for testing at small-scale the coherency of Macaronesia and its direct biogeographic units: i.e. the Azores, Webbnesia and Cabo Verde, as proposed in recent scientific literature. Additionally, this paper provides for the first time separate fishery statistics for this group in the region that were analysed to contrast the biogeographic results.
\end{abstract}

Keywords: moray eels; biogeography; fishery landings; dissimilarity; eastern Atlantic.

La familia Muraenidae: un grupo ideal para verificar a pequeña escala la coherencia de la Macaronesia como unidad biogeográfica, con primer informe de estadísticas pesqueras

Resumen: Este trabajo fue ideado para estudiar las especies de Muraenidae (morenas) presentes en aguas de los archipiélagos volcánicos de Azores, Madeira, Salvajes, Canarias y Cabo Verde (Atlántico centro-oriental), cuyos patrones biogeográficos fueron analizados y comparados. La hipótesis de partida fue que esta familia ictiológica es un grupo ideal para verificar, a pequeña escala, la coherencia de la Macaronesia y sus unidades biogeográficas directamente relacionadas -i.e. Azores, Webbnesia y Cabo Verde- propuestas en la literatura reciente. Además, este estudio proporciona, por primera vez, estadísticas pesqueras separadas de este grupo en la región que fueron analizadas para contrastar los resultados biogeográficos.

Palabras clave: morenas; biogeografía; descargas pesqueras; disimilitud; Atlántico oriental.

Citation/Como citar este artículo: González J.A., Correia S., Jiménez S., Monteiro C.A., Delgado J., Pinho M.R., Lorenzo J.M., González-Lorenzo G. 2021. The fish family Muraenidae: an ideal group for testing at small-scale the coherency of Macaronesia as a biogeographic unit, with the first report on separate fishery statistics. Sci. Mar. 85(3): 157-167. https:// doi.org/10.3989/scimar.05096.014

Editor: A. García Rubies.

Received: June 22, 2020. Accepted: March 25, 2021. Published: August 13, 2021.

Copyright: ( $\odot 2021$ CSIC. This is an open-access article distributed under the terms of the Creative Commons Attribution 4.0 International (CC BY 4.0) License. 


\section{INTRODUCTION}

Moray eels (Osteichthyes: Muraenidae) are a diverse group that are distributed worldwide in tropical and temperate seas from intertidal to deep waters. Adults are benthic, generally living in shallow water among rocks and coral heads; many species are more active at night and hide in holes, crevices and other shady zones during the day. Scavengers and predators, they feed mainly on benthic crustaceans, small fishes and cephalopods, but some species (Echidna) are durophagous. Their larvae (leptocephali) are epipelagic, widespread and abundant, and the species' dispersal success over a broad geographical range could putatively be attributed to their long larval stage (Bauchot 1986, Tang and Fielitz 2013, Froese and Pauly 2020). Moray eels are key components of the marine ecosystems, but their relationships remain poorly understood (Jiménez et al. 2007, Tang and Fielitz 2013).

The family Muraenidae is one of the largest and most recognizable eel groups. It is represented by 16 genera with 202 valid species according to Froese and Pauly (2020) and 217 species according to Fricke et al. (2020), 34 of which (belonging to eight genera) occur in the Atlantic Ocean and, of these, 26 (eight genera) occur in the eastern Atlantic (Froese and Pauly 2020). Anar- chias euryurus (Lea, 1913) is currently considered as a synonym of Anarchias longicauda (Peters, 1877) (Fricke et al. 2020) by taxonomic decision of Böhlke et al. (1989). Gymnothorax flavimarginatus (Rüppell, 1830) and Gymnothorax meleagris (Shaw, 1795) must be considered Indo-Pacific species, because their respective occurrences in Transkei and Algoa Bay, South Africa are in the Indian Ocean. The non-documented occurrence of Gymnothorax funebris Ranzani, 1839 at Cabo Verde is not accepted as valid, because we have found no report for this country, and nor have Wirtz et al. (2013).

The aim of this work is to study the muraenid species occurring around the volcanic archipelagos of the Azores, Madeira, Selvagens, Canary and Cabo Verde islands (eastern-central Atlantic), to analyse their biogeographic patterns and to compare this group composition among archipelagos. We then check whether the hypothesis that this fish group, due to its biological and biogeographic characteristics, can be used to test at small-scale the coherency of Macaronesia and its direct biogeographic units: i.e. the Azores, Webbnesia and Cabo Verde, as proposed in recent papers (Freitas et al. 2019). Additionally, for the first time separate landing statistics for this group are given and analysed by species or groups of species from each archipelago, to contrast the biogeographic results.

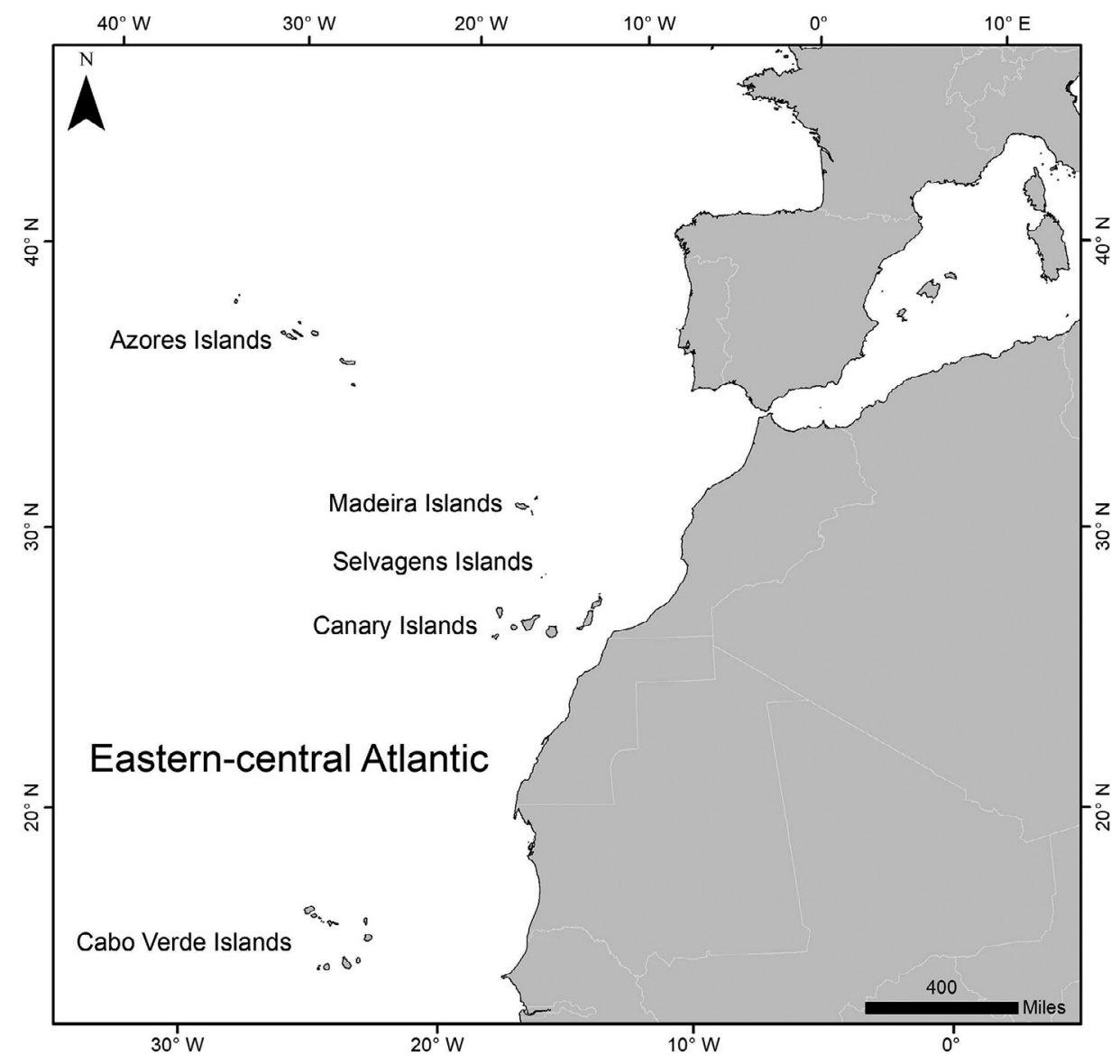

Fig. 1. - The archipelagos of the Azores, Madeira, Selvagens, Canary and Cabo Verde islands (eastern-central Atlantic Ocean). 


\section{MATERIALS AND METHODS}

\section{Study area and biogeographic analysis}

The present combined list covers all valid marine species of moray eels (Muraenidae) occurring around the volcanic archipelagos of the Azores, Madeira, Selvagens, Canary and Cabo Verde islands from intertidal to deep waters (Fig. 1).

Systematic classification and taxon arrangement follow FishBase (Froese and Pauly 2020) and Eschmeyer's Catalog of Fishes (Fricke et al. 2020). For each species, the occurrence at each archipelago was checked using the following main references: Santos et al. (1997) for the Azores; Wirtz et al. (2008) for Madeira; Falcón et al. (2000) and Almada et al. (2015) for the Selvagens; Brito et al. $(2002,2014)$ for the Canaries; and Brito et al. (1999), Menezes et al. (2004), Monteiro (2008), Wirtz et al. (2013), González et al. (2014) and Hanel and John (2015) for Cabo Verde. The main references shared by all archipelagos were Blache (1967), Bauchot (1986), Smith and Böhlke (1990), Smith (2012), Smith and Brito (2016) and Freitas et al. (2019). Also, for each species, common and total depth ranges were compiled.

Each species was classified into five biogeographic pattern categories as follows: circumtropical or pantropical (PANT); amphi-Atlantic of warm affinity (AAWA); Atlanto-Mediterranean (ATLM); Guinean restricted to tropical/subtropical eastern Atlantic (TSEA); and eastern-central Atlantic islands from the Azores to Cabo Verde islands and southwards to St. Helena islands (ECAI) (González 2018). To compare the taxon composition among archipelagos, the number of valid species was calculated. To compare the species' biogeographic patterns (affinity) among archipelagos, a description of different components of the family was performed according to the zoogeographic categories established above.

\section{Sources and analysis of landing statistics}

Data available on temporal series of landing statistics were taken from official sources: LOTAÇOR (Azores), the Direção Regional do Mar (Madeira); the website of the Canary Islands Government (www. gobiernodecanarias.org/agp/sgt/temas/estadistica/pesca/index.html) and the Instituto do Mar (former Instituto Nacional de Desenvolvimento das Pescas, INDP). In the case of Cabo Verde, disaggregated statistics by species or groups of species were reconstructed from estimated percentages based on relative abundances according to the literature (Monteiro 2008) and observations by the authors from experimental (e.g. Menezes et al. 2004, González et al. 2014) and professional catches and from local fish markets. These landings correspond entirely to catches in its harvested form made by small-scale fleets.

The analysis of variations in landing composition and their relationship to community changes at sea is more robust when disaggregated local landings from multi-specific and multi-gear fisheries are traceable (Fortibuoni et al. 2017). The main aspect to consider is the trend in indices over time rather than the absolute values they assume. With the landing information gathered, a standardized data matrix $((\mathrm{x}-\mathrm{mean}) / \mathrm{sd})$ was constructed, whose variables were the annual landings in the 2008-2018 period of the different species in each geographical area, as well as two variables that represent the aggregate landings of the unidentified muraenid species at the species level called Remaining_North (the Azores, Madeira and Canary islands) and Remaining_South (Cabo Verde). This distinction was due to the marked differences in the specific composition of these aggregates. In addition, a variable resulting from the relationship between the muraenid landings and the total demersal fish landings per year (Muraenidae_ LDF) was included, in order to weigh the importance of these resources in the different archipelagos.

To test for spatio-temporal differences in the $\mathrm{Mu}$ raenidae landings among the four geographical zones, a non-parametric ANOSIM two-way crossed test was performed on a distance-based similarity matrix (Clarke and Warwick 1994). When a significant difference $(\mathrm{p}<5 \%)$ was detected, a similarity percentage analysis (SIMPER) was conducted to determine the contribution of the variables to dissimilarities between samples grouped according to design factors (year and archipelago) (Clarke and Warwick 1994). Non-parametric multidimensional scaling ordination (nMDS) was used to examine the temporal behaviour of the landings grouped by geographical origin. All multivariate procedures were performed with the PRIMER v6 statistical package (Clarke and Gorley 2006).

\section{Brief description of the fishing techniques for moray eels in the region}

Moray eels are to a greater or lesser extent a popular food fish in the studied archipelagos. In the Azores, they are a bycatch or secondary target of fisheries rather than a fishery resource exploited as such. They are caught using longlines, handlines and fish traps (Gallagher et al. 2012) and are locally consumed at moderate levels. In Madeira, they are caught using handlines, small longlines and fish traps, and also with a highly selective trap. A traditional fishing modality during low tide was based on constrictor-knot devices, but it fell into disuse. This seafood is a snack enjoyed by many local fish consumers and tourists (Nunes 1994) and is also used in stews by some connoisseurs of the product. In the Canaries, it is much appreciated, and is exploited from the intertidal to deep waters using varied fishing gear: a highly selective trap ("tambor"), traditional fish traps, longlines, handlines, harpoons and constrictor-knot-based devices (González 1991, Franquet and Brito 1995, González et al. 2020a). Muraena augusti is the main target of a selective fishery with tambor in this archipelago. In the recent past, moray eels constituted a complementary food resource for a part of the regional agricultural population, which used ingenious fishing tools to catch them in the intertidal zone, including songs and whistles, making this practice part of popular folklore (Jiménez 1997). They currently have a relatively high gastronomic interest, especial- 
ly in typical restaurants. In Cabo Verde, they are very much appreciated and are caught from the intertidal to the intermediate shelves using harpoons and handlines (Monteiro 2008, González et al. 2020b) and with small longlines; none of the fish traps affect any demersal resource. They have a very high gastronomic interest, being the most typically consumed appetizer in the country. In the Canary and Cabo Verde islands they are also the object of sport fishing and poaching.

\section{RESULTS}

\section{Systematic checklist, biology and biogeographic patterns}

This systematic list includes a combined checklist of Muraenidae occurring at the five studied archipelagos supported by bibliographic references, as well as updated information on species' habitat and bathymetric range, geographic distribution and biogeographic pattern. The report of Echidna catenata (Bloch, 1795) from the Cabo Verde islands is a mistaken record (Wirtz et al. 2013). The muraenid species occurring in the currently studied archipelagos are presented in Table 1. A total of 18 muraenid moray eels are listed as follows.

Family Muraenidae Rafinesque, 1810

Subfamily Muraeninae Rafinesque, 1815

Echidna peli (Kaup, 1856)

Pebbletooth moray

On rocky shallow-water zones to at least $20 \mathrm{~m}$ depth. Distribution: Cabo Verde and the islands of São Tomé and Annobon in the Bay of Biafra; also on the west coast of Africa from Cape Blanc, Mauritania to Cape Lopez, Gabon. TSEA.

\section{Enchelycore anatina (Lowe, 1838)}

Fangtooth moray

On rocky bottoms at depths of 0 to $60 \mathrm{~m}$. An insular species in the eastern-central Atlantic from the Azores, Madeira (type locality), Selvagens, Canaries, Cabo Verde, Ascension (Wirtz et al. 2017), and St. Helena (Blache 1967); also in the western Atlantic from Bermuda (extinct due to habitat loss, Dulvy et al. 2003) to Brazil. An Atlantic range-expanding alien species within the Mediterranean, with records from Malta to Israel (Marletta and Lombardo 2020). AAWA.

\section{Enchelycore nigricans (Bonnaterre, 1788) Viper moray}

On rocky and coral areas from shallow waters to at least $60 \mathrm{~m}$ depth. Distribution: Cabo Verde, the islands of Bay of Biafra and Ascension Island, and from Senegal to Gabon; also in the western Atlantic from Bermuda, Bahamas, and Florida to Brazil, and in the western Pacific from Philippines (Villoso et al. 1983) and Taiwan (Huang 2001). PANT.

\section{Gymnothorax afer (Bloch, 1795)} Dark moray

On rocky bottoms in shallow waters from $10 \mathrm{~m}$ to at least $45 \mathrm{~m}$ depth. Reported from Cabo Verde and the islands of the Bay of Biafra, and on the west coast of Africa from Mauritania to Angola. TSEA.

\section{Gymnothorax bacalladoi (Böhlke and Brito, 1987) Canary moray}

On rocky and rubble bottoms from 5 to $20 \mathrm{~m}$ depth. The report of an individual at $604 \mathrm{~m}$ depth in Canaries

Table 1. - Combined checklist of muraenid moray eels occurring in the study area.

\begin{tabular}{|c|c|c|c|c|c|c|c|}
\hline Muraenidae & Depth range $(\mathrm{m})$ & Azores & Madeira & Selvagens & Canaries & Cabo Verde & Affinity \\
\hline \multicolumn{8}{|l|}{ Subfam. Muraeninae } \\
\hline Echidna peli & shallow-20 & 0 & 0 & 0 & 0 & 1 & TSEA \\
\hline Enchelycore anatina & $0-60$ & 1 & 1 & 1 & 1 & 1 & AAWA \\
\hline Enchelycore nigricans & $1-60$ & 0 & 0 & 0 & 0 & 1 & PANT \\
\hline Gymnothorax afer & $10-45$ & 0 & 0 & 0 & 0 & 1 & TSEA \\
\hline Gymnothorax bacalladoi & $5-20$ & 0 & 1 & 0 & 1 & 1 & ECAI \\
\hline Gymnothorax maderensis & $85-300$ & 0 & 1 & 0 & 1 & 1 & AAWA \\
\hline Gymnothorax miliaris & $0-60$ & 0 & 0 & 0 & 1 & 1 & AAWA \\
\hline Gymnothorax polygonius & $27-600$ & 0 & 1 & 0 & 1 & 1 & AAWA \\
\hline Gymnothorax unicolor & $0-300$ & 1 & 1 & 1 & 1 & 1 & ATLM \\
\hline Gymnothorax vicinus & $5-145$ & 0 & 0 & 0 & 1 & 1 & AAWA \\
\hline Monopenchelys acuta & $13-54$ & 0 & 0 & 0 & 0 & 1 & PANT \\
\hline Muraena augusti & $0-250$ & 1 & 1 & 1 & 1 & 1 & ECAI \\
\hline Muraena helena & $0-801$ & 1 & 1 & 1 & 1 & 1 & ATLM \\
\hline Muraena melanotis & shallow-45 & 0 & 0 & 0 & 0 & 1 & AAWA \\
\hline Muraena robusta & shallow-68 & 0 & 0 & 0 & 0 & 1 & AAWA \\
\hline \multicolumn{8}{|l|}{ Subfam. Uropterygiinae } \\
\hline Anarchias longicauda & $10-100$ & 1 & 1 & 0 & 1 & 1 & ATLM \\
\hline Channomuraena vittata & $5-100$ & 0 & 0 & 0 & 0 & 1 & PANT \\
\hline Uropterygius wheeleri & shallow & 0 & 0 & 0 & 0 & 1 & TSEA \\
\hline Sub-totals & & 5 & 8 & 4 & 10 & 18 & \\
\hline
\end{tabular}


is a labelling mistake (Brito et al. 2002). Distribution: Madeira, the Canary (type locality) and Cabo Verde islands. ECAI.

Gymnothorax maderensis (Johnson, 1862) Sharktooth moray

Among rocks and corals, at depths of 85 to $300 \mathrm{~m}$, mainly from $120 \mathrm{~m}$ depth. Distribution: Madeira (type locality), Canary and Cabo Verde islands, Meteor Seamount and Benin; also in the western Atlantic from Bermuda and North Carolina to Brazil (Carvalho Filho and Paiva 2017). AAWA.

Gymnothorax miliaris (Kaup, 1856) Goldentail moray

On coral reefs and rocky coasts, from shorelines to depths of $60 \mathrm{~m}$. In the eastern Atlantic it is an insular species inhabiting the Canary, Cabo Verde, Ascension and St. Helena islands; also in the western Atlantic from Bermuda, Bahamas and Florida to Brazil and St. Paul's Rocks, Trindade and Martin Vaz Islands. AAWA.

\section{Gymnothorax polygonius (Poey, 1875)} Polygon moray

On rocky substrates, mainly between 90 and $300 \mathrm{~m}$ depth, but rare records from 27 and $600 \mathrm{~m}$. Distribution: Madeira, Canary, Cabo Verde and St. Helena islands; also in the western Atlantic from North Carolina to Brazil. AAWA.

\section{Gymnothorax unicolor (Delaroche, 1809)} Brown moray

On rocky bottoms, commonly from shorelines to depths of $50 \mathrm{~m}$, but occasionally to $300 \mathrm{~m}$. Distribution: Azores, Madeira, Selvagens, Canary, Cabo Verde, Ascension (Wirtz et al. 2017) and St. Helena islands; also in Senegal, Morocco, southern Portugal, Spain, France (Béarez et al. 2017), and in the Tyrrhenian Sea (Spinelli and Castriota 2017). ATLM.

\section{Gymnothorax vicinus (Castelnau, 1855) Purplemouth moray}

On rocky and coral reef areas, also seagrass beds at depths between 5 and $145 \mathrm{~m}$; sometimes found in the open. Distribution: Canary and Cabo Verde islands, islands of the Bay of Biafra, and Ascension Island. Records from the Azores, Madeira and St. Helena are erroneous (Smith and Brito 2016). Also in the western Atlantic from Bermuda, the Bahamas and Florida south to Brazil. AAWA.

\section{Monopenchelys acuta (Parr, 1930) Redface moray}

On coral heads, rocky ledges and rubble bottoms at depths of 13 to $54 \mathrm{~m}$. Distribution: Cabo Verde and
Ascension islands; also in the western Atlantic islands of the Bahamas and Caribbean; and in the Indo-Pacific from the Hawaii, Fiji, Seychelles, Comoros and Agalega islands. PANT.

\section{Muraena augusti (Kaup, 1856)}

White-eyed moray, black moray

On littoral rocky bottoms and tide pools, where it lurks under big stones or in rock holes at depths of 0 to $250 \mathrm{~m}$, most frequently to $50 \mathrm{~m}$; occasionally found in the open in daytime. Distribution: Azores, Madeira (type locality), Selvagens, Canaries and Cabo Verde. ECAI.

\section{Muraena helena (Linnaeus, 1758) Mediterranean moray}

On rocky areas from shorelines to depths as great as $801 \mathrm{~m}$, more commonly to $300 \mathrm{~m}$; occasionally encountered in the open. Distribution: the Azores, Madeira, Selvagens, Canary, and Cabo Verde islands, and on the west coast of Africa from Rio de Oro, Western Sahara to Senegal. Also in the Mediterranean and the European coasts as far as Belgium, the British Isles and the Irish Sea (Quigley and Flannery 2004). ATLM.

\section{Muraena melanotis (Kaup, 1859) Honeycomb moray}

On rocky bottoms, from shallow waters to depths of $45 \mathrm{~m}$. Distribution: Cabo Verde and the islands of the Bay of Biafra; also on the west coast of Africa from Mauritania to Angola. Records from the Canary and St. Helena islands are erroneous (Smith and Brito 2016). Also known from Trinidad and Tobago (Ramjohn 1999), Brazil (Floeter et al. 2003) and St. Paul's Rocks (Feitoza et al. 2003) in the west Atlantic. AAWA.

\section{Muraena robusta (Osório, 1911) Stout moray}

On rocky areas from shallow waters to depths of $68 \mathrm{~m}$. Distribution: Cabo Verde (type locality) and the islands of the Bay of Biafra; also on the west coast of Africa from Mauritania to Angola. Records from the Canary Islands are erroneous (Smith and Brito 2016). Also in the western Atlantic from North Carolina to Colombia. AAWA.

Subfamily Uropterygiinae Fowler, 1925

$$
\begin{gathered}
\text { Anarchias longicauda (Peters, 1877) } \\
\text { Bluntnose moray }
\end{gathered}
$$

At depths of 10 to $100 \mathrm{~m}$. Distribution: the Azores, Madeira, Canary (Jiménez 1997), Cabo Verde (type locality) and Bay of Biafra islands; also on the west coast of Africa from Morocco to the Congo and in the western Mediterranean (at least from France, Béarez et al. 2017). ATLM. 
Channomuraena vittata (Richardson, 1845) Broadbanded moray

On rocky bottoms, in shallow waters at depths of 5 to $100 \mathrm{~m}$. Distribution: Cabo Verde and Annobon, São Tomé and Ascension islands; also in the western Atlantic and the Indo-West Pacific. PANT.

\section{Uropterygius wheeleri (Blache, 1967) Jigsaw moray}

In shallow waters. Distribution: Cabo Verde (type locality) and the islands of the Bay of Biafra; also on the west coast of Africa from Senegal. TSEA.

\section{Analysis of biogeographic patterns and comparison among archipelagos}

For each archipelago, the number of occurring genera and species and the percentage of species within each generic group are presented in Table 2, and the

Table 2. - Comparison (in numbers) of muraenid genera and species from the archipelagos studied, including the percentages of species by genera.

\begin{tabular}{|c|c|c|c|}
\hline & Genera & Species & Spp \% \\
\hline \multicolumn{4}{|l|}{ Azores } \\
\hline Echidna peli & 0 & 0 & 0 \\
\hline Enchelycore spp. & 1 & 1 & 50.0 \\
\hline Gymnothorax spp. & 1 & 1 & 14.3 \\
\hline Monopenchelys acuta & 0 & 0 & 0 \\
\hline Muraena spp. & 1 & 2 & 50.0 \\
\hline Anarchias longicauda & 1 & 1 & 100 \\
\hline Channomuraena vittata & 0 & 0 & 0 \\
\hline Uropterygius wheeleri & 0 & 0 & 0 \\
\hline \multicolumn{4}{|l|}{ Madeira } \\
\hline Echidna peli & 0 & 0 & 0 \\
\hline Enchelycore spp. & 1 & 1 & 50.0 \\
\hline Gymnothorax spp. & 1 & 4 & 57.1 \\
\hline Monopenchelys acuta & 0 & 0 & 0 \\
\hline Muraena spp. & 1 & 2 & 50.0 \\
\hline Anarchias longicauda & 1 & 1 & 100 \\
\hline Channomuraena vittata & 0 & 0 & 0 \\
\hline Uropterygius wheeleri & 0 & 0 & 0 \\
\hline \multicolumn{4}{|l|}{ Canaries } \\
\hline Echidna peli & 0 & 0 & 0 \\
\hline Enchelycore spp. & 1 & 1 & 50.0 \\
\hline Gymnothorax spp. & 1 & 6 & 85.7 \\
\hline Monopenchelys acuta & 0 & 0 & 0 \\
\hline Muraena spp. & 1 & 2 & 50.0 \\
\hline Anarchias longicauda & 1 & 1 & 100 \\
\hline Channomuraena vittata & 0 & 0 & 0 \\
\hline Uropterygius wheeleri & 0 & 0 & 0 \\
\hline \multicolumn{4}{|l|}{ Cabo Verde } \\
\hline Echidna peli & 1 & 1 & 100 \\
\hline Enchelycore spp. & 1 & 2 & 100 \\
\hline Gymnothorax spp. & 1 & 7 & 100 \\
\hline Monopenchelys acuta & 1 & 1 & 100 \\
\hline Muraena spp. & 1 & 4 & 100 \\
\hline Anarchias longicauda & 1 & 1 & 100 \\
\hline Channomuraena vittata & 1 & 1 & 100 \\
\hline Uropterygius wheeleri & 1 & 1 & 100 \\
\hline
\end{tabular}

number and percentage of species within each species' biogeographic pattern are presented in Table 3.

The Selvagens Islands are not included in this biogeographical analysis because, as a result of their small size, remote location and harsh sea conditions, only a few studies have been conducted to describe their marine species diversity (Almada et al. 2015).

Table 3. - Comparative description of biogeographic patterns for muraenid species from the archipelagos studied.

\begin{tabular}{|c|c|c|}
\hline Species' biogeographic pattern (affinity) & $\mathrm{N}$ & $\%$ \\
\hline \multicolumn{3}{|l|}{ Azores } \\
\hline Atlanto-Mediterranean (ATLM) & 3 & 60.00 \\
\hline Amphi-Atlantic of warm affinity (AAWA) & 1 & 20.00 \\
\hline Tropical and subtropical eastern Atlantic (TSEA) & 0 & 0 \\
\hline Pantropical or circumtropical (PANT) & 0 & 0 \\
\hline Eastern-central Atlantic islands (ECAI) & 1 & 20.00 \\
\hline Sub-totals & 5 & 100 \\
\hline \multicolumn{3}{|l|}{ Madeira } \\
\hline Atlanto-Mediterranean (ATLM) & 3 & 37.50 \\
\hline Amphi-Atlantic of warm affinity (AAWA) & 3 & 37.50 \\
\hline Tropical and subtropical eastern Atlantic (TSEA) & 0 & 0 \\
\hline Pantropical or circumtropical (PANT) & 0 & 0 \\
\hline Eastern-central Atlantic islands (ECAI) & 2 & 25.00 \\
\hline Sub-totals & 8 & 100 \\
\hline \multicolumn{3}{|l|}{ Canaries } \\
\hline Atlanto-Mediterranean (ATLM) & 3 & 30.00 \\
\hline Amphi-Atlantic of warm affinity (AAWA) & 5 & $\mathbf{5 0 . 0 0}$ \\
\hline Tropical and subtropical eastern Atlantic (TSEA) & 0 & 0 \\
\hline Pantropical or circumtropical (PANT) & 0 & 0 \\
\hline Eastern-central Atlantic islands (ECAI) & 2 & 20.00 \\
\hline Sub-totals & 10 & 100 \\
\hline \multicolumn{3}{|l|}{ Cabo Verde } \\
\hline Atlanto-Mediterranean (ATLM) & 3 & 16.67 \\
\hline Amphi-Atlantic of warm affinity (AAWA) & 7 & 38.90 \\
\hline Tropical and subtropical eastern Atlantic (TSEA) & 3 & 16.66 \\
\hline Pantropical or circumtropical (PANT) & 3 & 16.66 \\
\hline Eastern-central Atlantic islands (ECAI) & 2 & 11.11 \\
\hline Sub-totals & 18 & 100 \\
\hline
\end{tabular}

\section{Analysis of fishery landing statistics}

Separate statistics of muraenids for the Azores (over the 2002-2018 period), Madeira (2008-2019), Canary (2007-2019) and Cabo Verde islands (2008-2018) fishery landings are presented in Table 4; statistics were grouped by species or groups of species according to their availability at each regional/national source.

Separate landing statistics are given for the first time for moray eels, disaggregated by species or groups of species from each archipelago. Landings reached mean values (in metric tonnes per year, $\mathrm{t}^{-1}$ ) and percentages over total demersal landings as follows: $61.5 \mathrm{t} \mathrm{y}^{-1}$ $(1.8 \%)$ in the Azores, $1.9 \mathrm{t} \mathrm{y}^{-1}(0.001 \%)$ in Madeira, $103.7 \mathrm{t} \mathrm{y}^{-1}(6.3 \%)$ in the Canaries and $144.5 \mathrm{t} \mathrm{y}^{-1}(3.4 \%)$ in Cabo Verde. Within total muraenid landings at each archipelago, M. helena (70.9\% in weight) and G. unicolor $(25.0 \%)$ accounted for almost all landings in the Azores. M. helena represented $91.1 \%$ of landings in Madeira. M. helena (51.8\%) and M. augusti (27.4\%) accounted for a large volume of landings in the $\mathrm{Ca}$ - 
naries. G. vicinus $(42.0 \%), M$. robusta $(23.0 \%)$ and $M$. melanotis $(21.0 \%)$ were the most fished muraenids in Cabo Verde (Table 4).

The similarity analysis between samples only detected as significant differences those generated by the spatial factor (ANOSIM, R=0.981; $\mathrm{p}=0.02 \%$ ), considering the interannual variations to be non-significant $(\mathrm{R}=0.058 ; \mathrm{p}=78.6 \%)$. Differences between archipelagos were significant for all pairwises $(p<0.05 \%$ in all cases). The spatial segregation of the samples was evident in the ordination of the nMDS (Fig. 2), with those corresponding to Cabo Verde being placed to the right compared with the arrangement to the left of the remaining three archipelagos. In addition, the separation between these zones was also evident, as three well-differentiated groups were formed, composed exclusively of samples from each archipelago.

The marked differences between Cabo Verde landings and those of the other archipelagos were mainly due to their uneven specific composition, with the SIMPER analysis assigning the greatest contribution to the dissimilarity to the rest of the areas to the tropical species $M$. robusta, G. vicinus and $M$. melanotis (Table 5). One exception was observed in the case of the Canary Islands, where the analysis placed $M$. augusti at the same level of contribution as tropical species. In the northern archipelagos group, the greatest contribution of muraenid landings with respect to the total of demersal fish (Muraenidae_LDF) (Fig. 3), together with M. augusti landings, characterized the divergences of the Canary Islands from Madeira and the Azores, the values being in both cases higher in the Canaries. In turn, in this archipelago the volume of aggregate landings for unidentified muraenid species was much higher (Table 4).

\section{DISCUSSION}

\section{Verification of the coherence of the biogeographic units proposed for the region}

Moray eels of both subfamilies occur in all currently studied archipelagos. Of the 18 species identified, 5 occur in the Azores, 8 in Madeira, 10 in the Canaries and all 18 in Cabo Verde.

The genus Anarchias Jordan and Starks, 1906 and its direct child A. longicauda (an Atlanto-Mediterranean species that is the only Anarchias form in the region) occur in all the archipelagos. At a generic level, Channomuraena Richardson, 1848 (with the pantropical C. vittata), Uropterygius Rüppell, 1838 (with the Guinean $U$. wheeleri) and Echidna Forster, 1788 (with the Guinean E. peli) only occur in Cabo Verde. At a specific level, the pantropical $E$. nigricans and $M$. acuta, the amphi-Atlantic of warm affinity M. melanotis, and the Guinean G. afer and M. robusta only occur around Cabo Verde. These restricted occurrences markedly reflect a significant difference in the muraenid biota of the southermost archipelago in comparison with the others.

Madeira (8 species) and the Canary Islands (10 species) harbour a similar number of muraenid species, doubling the number in the Azores (5 species). Of these, 7 species are shared between Madeira and the

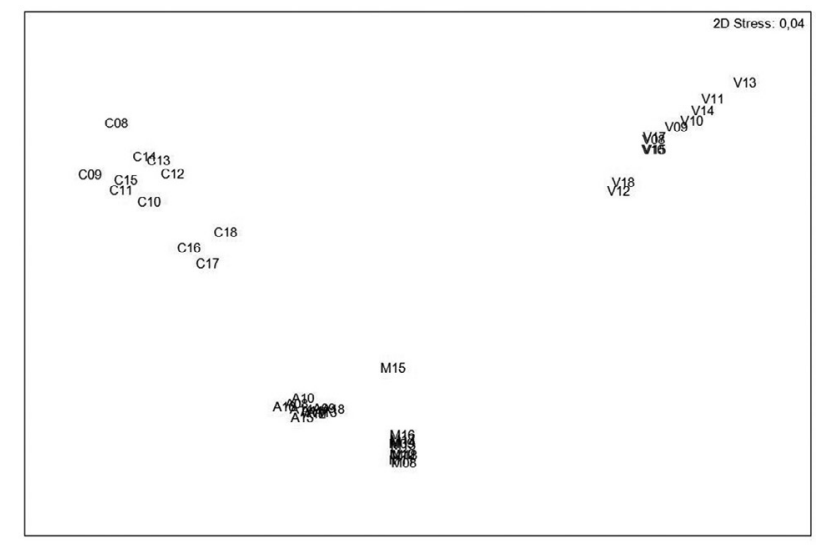

Fig. 2. - Non-metric multidimensional scaling ordination of muraenid landings for the 2008-2018 period. A, Azores; M, Madeira; C, Canary Islands; V, Cabo Verde.

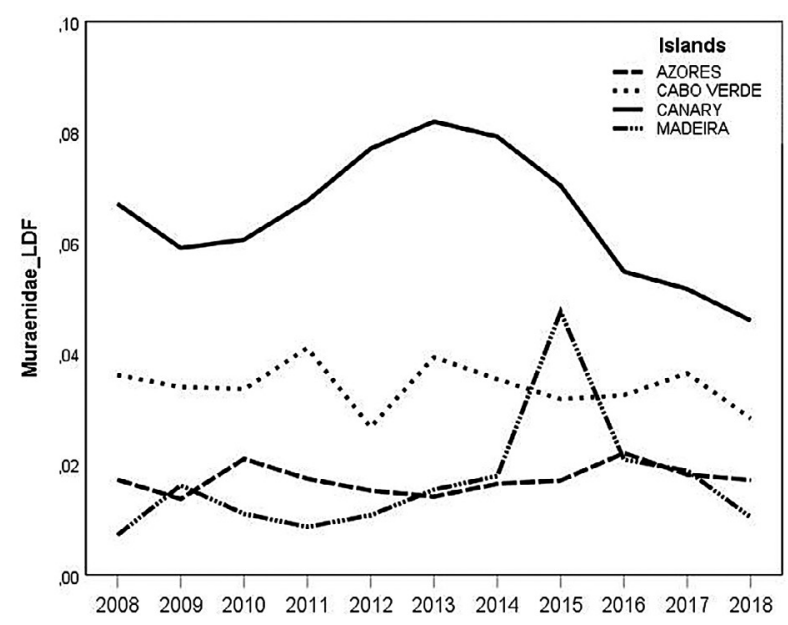

Fig. 3. - Relationships between landings of Muraenidae and demersal fish species (Muraenidae_LDF) in the four archipelagos during the study period.

Canary Islands, which are located in the central zone of the study area. Of these species, the endemic G. bacalladoi and the amphi-Atlantic of warm affinity $G$. maderensis and G. polygonius are not present in Azorean waters. These data suggest a significant difference in the muraenid biotas between the northermost and central archipelagos.

The amphi-Atlantic of warm affinity $G$. miliaris and G. vicinus are shared by Cabo Verde and the Canary islands. In fact, in the Canaries both species are restricted to a few localities of the westernmost islands with the warmest waters. However, in recent years these warm-affinity species seem to be trying to move towards the islands closer to the African coasts (some individuals have been caught in Tenerife and Gran Canaria), probably in the current scenario of tropicalization of fish assemblages in temperate biogeographic transition zones (Wirtz et al. 2008, Horta Costa et al. 2014).

The percentage of species of Gymnothorax Bloch, 1795 increases gradually from north to south, with the lowest value in the Azores (one species, 14.3\%) and the highest in Cabo Verde (seven species, 100\%). Val- 
$164 \cdot$ J.A. González et al.

Table 4. - Separate landing statistics for moray eels, disaggregated by species or groups of species at each archipelago studied.

\begin{tabular}{|c|c|c|c|c|c|}
\hline Year & Demersal fish species & Moray eels Muraenidae & $\begin{array}{c}\text { Mediterran. moray } \\
M . \text { helena }\end{array}$ & $\begin{array}{c}\text { Brown moray } \\
\text { G. unicolor }\end{array}$ & $\begin{array}{c}\text { Black moray } \\
\text { M. augusti }\end{array}$ \\
\hline \multicolumn{6}{|l|}{ Azores } \\
\hline 2002 & 3641000 & 64656 & 18185 & 44949 & 1522 \\
\hline 2003 & 3699000 & 81615 & 7737 & 69652 & 4226 \\
\hline 2004 & 3297000 & 81336 & 9254 & 70847 & 1235 \\
\hline 2005 & 3834000 & 65027 & 26004 & 35890 & 3133 \\
\hline 2006 & 3328000 & 69997 & 59537 & 4855 & 5605 \\
\hline 2007 & 3778000 & 62865 & 54921 & 3239 & 4705 \\
\hline 2008 & 3836000 & 65973 & 58073 & 3129 & 4771 \\
\hline 2009 & 3565000 & 48929 & 43359 & 2014 & 3556 \\
\hline 2010 & 2906000 & 60864 & 55054 & 2746 & 3064 \\
\hline 2011 & 3193000 & 55451 & 51338 & 2579 & 1534 \\
\hline 2012 & 3637000 & 55381 & 50162 & 3302 & 1917 \\
\hline 2013 & 3395000 & 48000 & 43000 & 3000 & 2000 \\
\hline 2014 & 3728000 & 61344 & 55296 & 2788 & 3260 \\
\hline 2015 & 3600000 & 61418 & 56726 & 3996 & 696 \\
\hline 2016 & 3172000 & 69755 & 64232 & 4907 & 616 \\
\hline 2017 & 2793000 & 50562 & 49050 & 1269 & 243 \\
\hline 2018 & 2514000 & 43055 & 39499 & 2728 & 828 \\
\hline Totals (kg) & 57916000 & 1046228 & 741427 & 261890 & 42911 \\
\hline Average $\left(\mathrm{kg} \mathrm{y}^{-1}\right)$ & 3406824 & 61543 & 43613 & 15405 & 2524 \\
\hline$\%$ & 100 & 1.8 & & & \\
\hline \multirow[t]{2}{*}{$\%$} & & 100 & 70.9 & 25.0 & 4.1 \\
\hline & Demersal fish species & Moray eels Muraenidae & $\begin{array}{c}\text { Mediterran. moray } \\
M . \text { helena }\end{array}$ & $\begin{array}{c}\text { Black moray } \\
\text { M. augusti }\end{array}$ & $\begin{array}{l}\text { Remaining } \\
\text { moray eels }\end{array}$ \\
\hline \multicolumn{6}{|l|}{ Madeira } \\
\hline 2008 & 353009 & 2537 & 2341 & 182 & 14 \\
\hline 2009 & 243942 & 3945 & 3853 & 78 & 14 \\
\hline 2010 & 248164 & 2736 & 2593 & 128 & 16 \\
\hline 2011 & 253163 & 2199 & 2048 & 133 & 18 \\
\hline 2012 & 200643 & 2162 & 2050 & 93 & 20 \\
\hline 2013 & 99657 & 1535 & 1401 & 113 & 21 \\
\hline 2014 & 84872 & 1516 & 1257 & 236 & 24 \\
\hline 2015 & 37334 & 1775 & 1648 & 102 & 25 \\
\hline 2016 & 31272 & 652 & 578 & 46 & 28 \\
\hline 2017 & 61725 & 1162 & 978 & 154 & 30 \\
\hline 2018 & 104334 & 1087 & 783 & 272 & 33 \\
\hline 2019 & 98479 & 1374 & 1122 & 207 & 45 \\
\hline Totals (kg) & 1816592 & 22681 & 20652 & 1741 & 288 \\
\hline Average $\left(\mathrm{kg} \mathrm{y}^{-1}\right)$ & 151383 & 1890 & 1721 & 145 & 24 \\
\hline$\%$ & 100 & 0.001 & & & \\
\hline$\%$ & & 100 & 91.1 & 7.7 & 1.3 \\
\hline Year & Demersal fish species & Moray eels Muraenidae & $\begin{array}{l}\text { Mediterran. moray } \\
M . \text { helena }\end{array}$ & $\begin{array}{l}\text { Black moray } \\
\text { M. augusti }\end{array}$ & $\begin{array}{l}\text { Remaining } \\
\text { moray eels }\end{array}$ \\
\hline \multicolumn{6}{|l|}{ Canaries } \\
\hline 2007 & 1243891 & 98722 & 43291 & 28010 & 27421 \\
\hline 2008 & 1916026 & 128476 & 54241 & 35846 & 38389 \\
\hline 2009 & 2202154 & 130056 & 69522 & 41992 & 18542 \\
\hline 2010 & 1888089 & 114362 & 66139 & 29498 & 18725 \\
\hline 2011 & 1751278 & 118355 & 68311 & 34065 & 15979 \\
\hline 2012 & 1216225 & 93687 & 50706 & 24441 & 18540 \\
\hline 2013 & 1261441 & 103325 & 61515 & 23339 & 18471 \\
\hline 2014 & 1403213 & 111104 & 61391 & 27556 & 22156 \\
\hline 2015 & 1685855 & 118602 & 65616 & 32667 & 20319 \\
\hline 2016 & 1774097 & 97239 & 57489 & 24012 & 15738 \\
\hline 2017 & 1676619 & 86577 & 49701 & 23085 & 13791 \\
\hline 2018 & 1623417 & 74617 & 25223 & 25240 & 24154 \\
\hline 2019 & 1647079 & 73297 & 25299 & 20359 & 27638 \\
\hline Totals (kg) & 21289383 & 1348419 & 698444 & 370110 & 279864 \\
\hline Average $\left(\mathrm{kg} \mathrm{y}^{-1}\right)$ & 1637645 & 103725 & 53726 & 28470 & 21528 \\
\hline$\%$ & 100 & 6.3 & & & \\
\hline$\%$ & & 100 & 51.8 & 27.4 & 20.8 \\
\hline
\end{tabular}


Table 4. (Cont.) - Separate landing statistics for moray eels, disaggregated by species or groups of species at each archipelago studied.

\begin{tabular}{|c|c|c|c|c|c|}
\hline Year & Demersal fish species & Moray eels Muraenidae & $\begin{array}{l}\text { Purplemouth moray } \\
\text { G. vicinus }\end{array}$ & $\begin{array}{l}\text { Stout moray } \\
M . \text { robusta }\end{array}$ & $\begin{array}{c}\text { Honeycomb moray } \\
M \text { melanotis }\end{array}$ \\
\hline \multicolumn{6}{|l|}{ Cabo Verde } \\
\hline 2008 & 3793000 & 137000 & 57540 & 31510 & 28770 \\
\hline 2009 & 4360000 & 148000 & 62160 & 34040 & 31080 \\
\hline 2010 & 4618000 & 155000 & 65100 & 35650 & 32550 \\
\hline 2011 & 4050000 & 166000 & 69720 & 38180 & 34860 \\
\hline 2012 & 4310000 & 115000 & 48300 & 26450 & 24150 \\
\hline 2013 & 4575000 & 180000 & 75600 & 41400 & 37800 \\
\hline 2014 & 4553000 & 161000 & 67620 & 37030 & 33810 \\
\hline 2015 & 4286000 & 136000 & 57120 & 31280 & 28560 \\
\hline 2016 & 4156000 & 135000 & 56700 & 31050 & 28350 \\
\hline 2017 & 3789000 & 138000 & 57960 & 31740 & 28980 \\
\hline 2018 & 4174000 & 118000 & 49560 & 27140 & 24780 \\
\hline Totals (kg) & 46664000 & 1589000 & 667380 & 365470 & 333690 \\
\hline Average $\left(\mathrm{kg} \mathrm{y}^{-1}\right)$ & 4242182 & 144455 & 60671 & 33225 & 30335 \\
\hline$\%$ & 100 & 3.4 & & & \\
\hline$\%$ & & 100 & 42.0 & 23.0 & 21.0 \\
\hline
\end{tabular}

Table 5. - Contribution to the dissimilarity between archipelagos of the variables included in the analysis according to the SIMPER routine. Contrib\%, contribution to the average dissimilarity; Muraenidae_LDF, annual landings of Muraenidae/annual landings of demersal fish; Remaining_N, aggregate landings at family level (Azores, Madeira and Canary Islands); Remaining_S, aggregate landings at family level (Cabo Verde).

\begin{tabular}{|c|c|c|c|c|c|}
\hline Azores - Madeira & & Azores - Canaries & \multicolumn{3}{|c|}{ Madeira - Canaries } \\
\hline Species & Contrib\% & Species & Contrib\% & Species & Contrib\% \\
\hline M. helena & 91.38 & Muraenidae LDF & 44.92 & M. augusti & 33.39 \\
\hline Muraenidae LDF & 6.75 & M. augusti & 42.59 & Muraenidae LDF & 31.86 \\
\hline M. augusti & 0.97 & Remaining $\mathrm{N}$ & 10.58 & M. helena & 25.2 \\
\hline Remaining_N & 0.91 & M. helena & 1.9 & Remaining $\mathrm{N}$ & 9.54 \\
\hline Azores - Cabo Verde & & Canaries - Cabo Verde & \multicolumn{3}{|c|}{ Madeira - Cabo Verde } \\
\hline Species & Contrib $\%$ & Species & Contrib\% & Species & Contrib $\%$ \\
\hline M. robusta & 21.02 & M. augusti & 15.45 & M. robusta & 24.01 \\
\hline G. vicinus & 21.02 & M. robusta & 15.42 & G. vicinus & 24.01 \\
\hline M. melanotis & 21.02 & G. vicinus & 15.42 & M. melanotis & 24.01 \\
\hline Remaining $\mathrm{S}$ & 21.02 & M. melanotis & 15.42 & Remaining $\mathrm{S}$ & 24.01 \\
\hline M. helena & 13.23 & Remaining $\mathrm{S}$ & 15.42 & Muraenidae LDF & 3.95 \\
\hline Muraenidae LDF & 2.42 & M. helena & 12.32 & M. helena & 0.02 \\
\hline M. augusti & 0.14 & Muraenidae LDF & 6.19 & & \\
\hline Remaining $\mathrm{N}$ & 0.12 & Remaining $\overline{\mathrm{N}}$ & 4.39 & & \\
\hline
\end{tabular}

ues for Madeira (four species, $57.1 \%$ ) and the Canaries (six species, $85.7 \%$ ) differ markedly from the ones for the Azores and Cabo Verde. Moreover, Cabo Verde once again stands out from the other archipelagos, also reaching $100 \%$ for the other genera of the family.

The combined percentage of warm-affinity species increases gradually from north to south, with the lowest value in the Azores (one AAWA species, 20.00\%) and the highest in Cabo Verde (13 species, $75.00 \%$, of which 7 AAWA, 3 TSEA and 3 PANT). In the Azores, Madeira and the Canary Islands there areno representative moray eels of TSEA or PANT zoogeographic categories, which are exclusive to Cabo Verde. Conversely, it can be also observed that the percentage of Atlanto-Mediterranean moray eels decreases gradually from north to south, with the the highest value in the Azores (three species, $60.00 \%$ ) and the lowest in Cabo Verde (three, 16.67\%). Finally, values of warm-affinity species for Madeira (three, $37.50 \%$ ) and the Canaries (five, 50.00\%) clearly differ from the ones for the Azores and Cabo Verde.
This set of evidence suggests that the Cabo Verde islands have a divergent muraenid taxon composition with a high level of dissimilarity, supporting the hypothesis that this tropical archipelago forms its own ecoregion biogeographically within the West African Transition province of the Tropical Atlantic realm (Spalding et al. 2007). The present results also support the argument that Cabo Verde should be given the status of a biogeographic sub-province within the above-mentioned province (Freitas et al. 2019). In the northern part of the study area, the Azores also exhibit marked differences in the composition of taxa, with a high level of dissimilarity, suggesting that this temperate archipelago should be given the status of its own ecoregion within the Lusitanian province of the Temperate Northern Atlantic realm (Freitas et al. 2019). Madeira and the Canaries share most of the taxon composition, with a high level of similarity between them, and they also show marked zoogeographic differences from the Azores northwards and the Cabo Verde southwards. Therefore, in agreement with Freitas 
et al. (2019), a new ecoregion, Webbnesia, comprising Madeira, Selvagens and the Canary Islands should be defined within the Lusitanian province.

Because of its taxonomic composition and biological and biogeographic characteristics, the family Muraenidae has successfully tested the starting hypothesis as an ideal group for verifying the coherence of the biogeographic units proposed for the region in the recent scientific literature.

\section{First report on separate landing statistics for moray eels in the region}

Neither the first edition (Böhlke 1981) nor the most recent edition (Smith and Brito 2016) of the FAO Species Identification Sheets for Fishery Purposes for the eastern-central Atlantic (fishing area 34, 47 in part) contain fishery statistics referring to muraenid moray eels. The same applies to FAO fishing area 10.a.2 (Azores).

As expected, the study of the landings of the analysed species corroborates the differences between the archipelagos highlighted in the biogeographic analysis. In the case of Cabo Verde, the variations compared with the other areas were mainly due to the different specific composition arising from the greater relative importance of warm-affinity species. At the other extreme is the Azores, whose landings had the lowest biodiversity, with only three species represented and dominated by $M$. helena. Although the specific composition of the landings was similar in Madeira and the Canary Islands, however, significant differences were found between both archipelagos that would be in disagreement with the biogeographic unit (Webbnesia) proposed by Freitas et al. (2019). Such divergences are mainly due to the fact that the volume of the landings of this group together with the relative importance of $M$. augusti in the Canaries distinguished this archipelago from the rest of the northern islands (Madeira and the Azores). Furthermore, the contribution of the aggregate landings, mainly consisting of $G$. polygonius and $G$. unicolor, was much higher than that obtained in Madeira and the Azores. In the last five years, the fishing activity of the métier targeting demersal resources in Madeira recorded an effort (fishing days) that was always less than 1500 days and a total volume of landings of less than $100 \mathrm{t}$, while in the Canaries the effort was always greater than 28000 fishing days and the landings varied from just over 1000 to over $2000 \mathrm{t}$ in 2018 (RCG 2019).

Therefore, the Canary Islands differ within the central biogeographic group because of socioeconomic factors, as these resources are highly appreciated and demanded by the population. This archipelago also differs from the fishing point of view, with the use of a specific and a highly selective gear (tambor), which is used from the shallow and provides high catches of $M$. augusti and, to a lesser extent, of $G$. unicolor. High catches of muraenid fish are made as bycatch in the pandalid shrimp fishery using bottom traps, which are deployed deeper and catch mainly $M$. helena and secondly G. polygonius (González et al. 2020a). In addition, the Canary Islands have a larger area of fishing grounds.
Fishery statistics are the primary tool for measuring the performance of a fishery within the social, economic, biological and environmental framework in which it is conducted. The need for reliable and comprehensive statistics has always been extremely important, particularly at present because they form the essential basis for planning sustainable fishing and environmental protection within the precautionary approach. Regional databases are required to conduct studies on shared resources of transboundary fish stocks, and development of regional databases is essentially a matter of standardization and harmonization (Bazigos 1983, Stamatopoulos 2002). Demersal resources, and particularly the moray eel landings, should be monitored regularly, and it is recommended to take management actions to ensure that their stocks are not depleted further.

\section{ACKNOWLEDGEMENTS}

In memoriam of the Spanish marine biologist Professor Ignacio Lozano (1958-2008), as a tribute to his valuable research legacy. This study received logistic support from the Projects MARISCOMAC (MAC/2.3d/097) and MACAROFOOD (MAC/2.3d/015) in the framework of the EU Programme INTERREG V-A (Madeira, Açores, Canarias) 2014-2020.

\section{REFERENCES}

Almada F., Abecasis D., Villegas-Ríos D., et al. 2015. Ichthyofauna of the Selvagens Islands. Do small coastal areas show high species richness in the northeastern Atlantic? Mar. Biol. Res. 11: 49-61. https://doi oro/10.1080/17451000.2014889306

Bauchot M.L. 1986. Muraenidae. In: Whitehead P.J.P., Bauchot M.L., Hureau J.C., et al. (eds), Fishes of the North-eastern Atlantic and the Mediterranean, vol. 3. UNESCO, Paris, pp. 537-544.

Bazigos G.P. 1983. Applied Fishery Statistics. FAO Fish. Tech. Pap. 135: 1-164.

Béarez P., Pruvost P., Feunteun É., et al. 2017. Checklist of the marine fishes from metropolitan France. Cybium 41: 351-371. https://doi.org/10.26028/cybium/2017-414-006

Blache J. 1967. Contribution à la connaissance des Poissons Anguilliformes de la côte occidentale d'Afrique. Quatrième note. Le genre Lycodontis Mc Clelland, 1845. Bull. IFAN 29: 1122-1187.

Böhlke J.E. 1981. Ophichthidae, Muraenidae. In: Fischer W., Bianchi G., Scott W.B. (eds), FAO species identification sheets for fishery purposes; Eastern Central Atlantic fishing areas, 34, 47 (in part), vol. 3. Canada Funds-in-Trust, Ottawa; FAO, Rome.

Böhlke E.B., Brito A. 1987. Gymnothorax bacalladoi, a new moray from the Canary Islands (Pisces: Muraenidae). Proc. Acad. Nat. Sci. Philadelphia 139: 459-463.

Böhlke E.B., McCosker J.E., Böhlke J.E. 1989. Family Muraenidae. In: Böhlke E.B. (ed), Fishes of the western North Atlantic. Mem. Sears Found. Mar. Res. 9: 1-655.

Brito A., Herrera R., Falcón J.M., et al. 1999. Contribución al conocimiento de la ictiofauna de las islas de Cabo Verde. Rev. Acad. Canaria Cienc. 11: 27-41.

Brito A., Pascual P.J., Falcón J.M., et al. 2002. Peces de las Islas Canarias. Catálogo comentado e ilustrado. Francisco Lemus Editor, La Laguna, 419 pp.

Brito A., Dorta C., Falcón J.M. 2014. First valid record of Gymnothorax vicinus (Pisces: Muraenidae) for Macaronesian ecoregion (Canary Islands): A process of tropicalization? Rev. Acad. Canaria Cienc. 26: 71-78.

Carvalho Filho A., Paiva M.I.G. 2017. New records of marine 
eels (Teleostei: Anguilliformes) from Brazilian waters. Check List 13: 2092 https://doi.org/10.15560/13.2.2092

Clarke K.R., Gorley R.N. 2006. PRIMER v6: User Manual/Tutorial. PRIMER-E, Plymouth, 192 pp.

Clarke K.R., Warwick R.M. 1994. Change in Marine Communities. Plymouth Marine Laboratory, Plymouth, 144 pp.

Dulvy N.K., Sadovy Y., Reynolds J.D. 2003. Extinction vulnerability in marine populations. Fish Fish. 4: 25-64. https://doi.org/10.1046/j.1467-2979.2003.00105.x

Falcón J.M., García-Charton J.A., Brito A., et al. 2000. Peces litorales de las Islas Salvajes. Rev. Acad. Canaria Cienc. 12: 137-142.

Feitoza B.M., Rocha L.A., Luiz-Júnior O.J., et al. 2003. Reef fishes of St. Paul's Rocks: new records and notes on biology and zoogeography. Aqua, J. Ichthyol. Aquat. Biol. 7: 61-82.

Floeter S.R., Gasparini J.L., Rocha L.A., et al. 2003. Brazilian reef fish fauna: checklist and remarks (updated Jan. 2003). Brazilian Reef Fish Project: www.brazilianreeffish.cjb.net.

Fortibuoni T., Giovanardi O., Pranovi F., et al. 2017. Corrigendum: Analysis of long-term changes in a Mediterranean marine ecosystem based on fishery landings. Front. Mar. Sci. 4: 1-16. https://doi.org/10.3389/fmars.2017.00204

Franquet F., Brito A. 1995. Especies de interés pesquero de Canarias. Gobierno de Canarias, Santa Cruz de Tenerife, 143 pp.

Freitas R., Romeiras M., Silva L., et al. 2019. Restructuring of the 'Macaronesia' biogeographic unit: A marine multi-taxon biogeographical approach. Scient. Rep. 9: 15792 (2019). https://doi.org/10.1038/s41598-019-51786-6

Fricke R., Eschmeyer W.N., van der Laan R. (eds). 2020. Eschmeyer's Catalog of Fishes: Genera, Species, References. https://www.calacademy.org/scientists/projects/eschmeyers-catalog-of-fishes

Froese R., Pauly D. (eds). 2020. FishBase. World Wide Web electronic publication. www.fishbase.org, version (12/2020).

Gallagher L., Porteiro F., Dâmaso C., et al. 2012. Consumer's guide to Azorean seafood. Universidade dos Açores, $102 \mathrm{pp}$.

González J.A. 1991. Description générale des pêcheries artisanales aux îles Canaries. In: Durand J.R., Lemoalle J., Weber J. (eds), La Recherche Face à la Pêche Artisanale / Research and small-scale fisheries, vol. 1. ORSTOM, Paris, pp. $365-370$.

González J.A. 2018. Checklists of Crustacea Decapoda from the Canary and Cape Verde Islands, with an assessment of Macaronesian and Cape Verde biogeographic marine ecoregions. Zootaxa 4413: 401-448. https://doi.org/10.11646/zootaxa.4413.3.1

González J.A., Martins A., Santana J.I., et al. 2014. New and rare records of fishes (Osteichthyes) from the Cape Verde Islands (eastern-central Atlantic Ocean). Cybium 38: 289-300. https://doi.org/10.26028/cybium/2014-384-007

González J.A., González-Lorenzo G., Tejera G., et al. 2020a. Artisanal fisheries in the Canary Islands (eastern-central Atlantic): description, analysis of their economic contribution, current menaces, and strategic actions for sustainable development. Acta Ichthyol. Piscat. 50: 269-289. https://doi.org/10.3750/AIEP/02963

González J.A., Monteiro C.A., Correia S., et al. 2020b. Current and emerging small-scale fisheries and target species in Cabo Verde, with recommendations of pilot actions for sustainable development. Cybium 44: 355-371. https://doi.org/10.26028/cybium/2020-444-006

Hanel R., John H.C. 2015. A revised checklist of Cape Verde Islands sea fishes. J. Appl. Ichthyol. 31: 135-169. https://doi.org/10.1111/jai.12621

Horta Costa B., Assis J., Franco G., et al. 2014. Tropicalization of fish assemblages in temperate biogeographic transition zones. Mar. Ecol. Prog. Ser. 504: 241-252. https://doi.org/10.3354/meps10749

Huang Z. 2001. Marine species and their distribution in China's seas. In: Vertebrata. Smithsonian Institution, Florida, pp. 404-463.

Jiménez S. 1997. Taxonomía, biología y pesca de las especies de la familia Muraenidae (Osteichthyes, Anguilliformes) en las islas Canarias. PhD thesis, Universidad de La Laguna, 676 pp.

Jiménez S., Schönhuth S., Lozano I.J., et al. 2007. Morphological, ecological and molecular analyses separate Muraena augusti from Muraena helena as a valid species. Copeia 1007: 101-113. https://doi.org/10.1643/0045-8511(2007)7[101:MEAMAS]2.0. $\mathrm{CO} ; 2$
Marletta G., Lombardo A. 2020. Undergoing invasion of the fangtooth moray Enchelycore anatina (Lowe, 1838) in the western Ionian Sea, Central Mediterranean. BioInvasions Rec. 9: 195-203. https://doi.org/10.3391/bir.2020.9.2.04

Menezes G.M., Tariche O., Pinho M.R., et al. 2004. Annotated list of fishes caught by the R/V ARQUIPÉLAGO off the Cape Verde archipelago. Arquipélago, Life Mar. Sci. 21A: 57-71.

Monteiro V.M.S. 2008. Peixes de Cabo Verde com valor comercial. $2^{a}$ edição. VMS Monteiro Editora, São Vicente, 183 pp.

Nunes A.A. 1994. Peixes da Madeira. Junta Geral do Distrito Autónomo, Funchal, 284 pp.+25 estampas.

Quigley D.T.G., Flannery K. 2004. First record of the moray eel Muraena helena L. from Irish waters and a review of NW European records. Irish Nat. J. 27: 426-428.

Ramjohn D.D. 1999. Checklist of coastal and marine fishes of Trinidad and Tobago. Fisheries Information Series 8: 1-151. Ministry of Agriculture, Land and Marine Resources, Trinidad and Tobago.

Regional Coordination Group (RCG). 2019. Regional Coordination Group Long Distance Fisheries. 56 pp. (https://datacollection.jrc.ec.europa.eu/docs/rcg).

Santos R.S., Porteiro F.M., Barreiros J.P. 1997. Marine fishes of the Azores. Annotated checklist and bibliography. A catalogue of the Azorean marine ichthyodiversity. Arquipélago, Life Mar. Sci. (Suppl. 1): i-xxvii + 1-244. https://doi.org/10.13140/2.1.2002.4649

Smith D.G. 2012. A checklist of the moray eels of the World (Teleostei: Anguilliformes: Muraenidae). Zootaxa 3474: 1-64. https://doi.org/10.11646/zootaxa.3474.1.1

Smith D.G., Böhlke E.B. 1990. Muraenidae. In: Quéro J.C., Hureau J.C., Karrer C., et al. (eds), Check-list of the fishes of the Eastern tropical Atlantic, vol. 3. JNICT, Lisbon; SEI and UNESCO, Paris, pp. 136-148.

Smith D.G., Brito A. 2016. Muraenidae. In: Carpenter K.E., De Angelis N. (eds), The living marine resources of the Eastern Central Atlantic, vol. 3: Bony fishes part 1 (Elopiformes to Scorpaeniformes). FAO Species Identification Guide for Fishery Purposes. FAO, Rome, pp. 1614-1642.

Spalding M.D., Fox H.E., Allen G.R., et al. 2007. Marine ecoregions of the world: A bioregionalization of coastal and shelf areas. BioScience 57: 573-583. https://doi.org/10.1641/B570707

Spinelli A., Castriota L. 2017. A new record of Gymnothorax unicolor (Muraenidae) in the southern Tyrrhenian Sea. Mar. Biodiv. 47: 785-786. https://doi.org/10.1007/s12526-016-0512-3

Stamatopoulos C. 2002. Sample-Based Fishery Surveys - A Technical Handbook. FAO Fish. Tech. Pap. 425: 1-132.

Tang K.L., Fielitz C. 2013. Phylogeny of moray eels (Anguilliformes: Muraenidae), with a revised classification of true eels (Teleostei: Elopomorpha: Anguilliformes). Mitochondrial DNA 24: 55-66. https://doi.org/10.3109/19401736.2012.710226

Villoso E.P., Hermosa G.V., Dizon C. 1983. Species composition and diversity of fishes caught by otter trawling in Samar Sea. Fish. Res. J. Philipp. 8: 33-49.

Wirtz P., Fricke R., Biscoito M.J. 2008. The coastal fishes of Madeira Island-new records and an annotated check-list. Zootaxa 1715: 1-26. https://doi.org/10.11646/zootaxa.1715.1.1

Wirtz P., Brito A., Falcón J.M., et al. 2013. The coastal fishes of the Cape Verde Islands - new records and an annotated check-list. Spixiana 36: 113-142.

Wirtz P., Bingeman J., Bingeman J., et al. 2017. The fishes of Ascension Island, central Atlantic Ocean - new records and an annotated checklist. J. Mar. Biol. Assoc. U.K. 97(4): 783-798. https://doi.org/10.1017/S0025315414001301 